\title{
Divergent roles for ferric ions in the biological activity of amidated and non-amidated gastrins
}

\author{
J Pannequin, J-P Tantiongco, S Kovac, A Shulkes and \\ G S Baldwin
}

University of Melbourne Department of Surgery, Austin Campus, A\&RMC, Studley Road, Heidelberg, Victoria 3084, Australia

(Requests for offprints should be addressed to G S Baldwin; Email: grahamsb@unimelb.edu.au)

\begin{abstract}
Amidated forms of the peptide hormone gastrin act via the cholecystokinin-2 receptor to stimulate gastric acid secretion, whereas non-amidated forms stimulate colonic mucosal proliferation via a novel, as yet uncharacterised, receptor. Nuclear magnetic resonance (NMR) and fluorescence spectroscopic studies have revealed that glycineextended gastrin 17 bound two ferric ions, and that ferric ion binding was essential for biological activity. We have therefore investigated the role of ferric ions in the biological activity of amidated gastrin 17 . As with glycineextended gastrin17, fluorescence quenching experiments indicated that Glu7 Ala and Glu8,9 Ala mutants of amidated gastrin 17 each bound only one ferric ion. The affinity of the mutant peptides for the cholecystokinin-2 receptor on transfected COS-7 cells or on $\mathrm{T}$ lymphoblastoid Jurkat cells, and their potency in stimu-
\end{abstract}

lation of proliferation in Jurkat cells and inositol phosphate production in transfected COS-7 cells, were similar to the values obtained for amidated gastrin17. In addition, the iron chelator desferrioxamine did not significantly inhibit either binding of amidated gastrin17 to the cholecystokinin-2 receptor, or stimulation of inositol phosphate production by amidated gastrin 17 in transfected COS-7 cells. We conclude that, in contrast to glycineextended gastrin17, binding of ferric ions is not essential for the biological activity of amidated gastrin17. Our results support the concept of distinct modes of action for amidated and non-amidated gastrins, and raise the possibility of developing selective antagonists of the actions of non-amidated and amidated gastrins.

Journal of Endocrinology (2004) 181, 315-325

\section{Introduction}

Many peptide hormones are synthesised as precursors that undergo proteolytic cleavage and post-translational processing to form the mature amidated hormone (Prigge et al. 2000). Although C-terminal amidation was thought to be essential for the bioactivity of most peptide hormones, there are an increasing number of examples where a glycine-extended intermediate is also bioactive. Examples include secretin-gly, gastrin releasing peptide (GRP)-gly, glucagon-like peptide (GLP)-1-gly and substance P (Wettergren et al. 1998, Abou-Mohamed et al. 2000, Oiry et al. 2000, Solomon et al. 2001). However, these glycine-extended forms either interact with the same receptor type as the amidated form or are converted to the mature form close to the site of action.

Gastrin is synthesised as a precursor (progastrin) that is processed via a glycine-extended form (Ggly) to the amidated hormone (Gamide) (Dockray 1999). In addition to regulating gastric acid secretion, the peptide hormone gastrin stimulates the growth of the gastric mucosa in vivo and various gastrointestinal cell lines in vitro (Baldwin 1995a, Dockray et al. 2001). Recently, several groups have also described a significant effect of gastrins on cell migration (De Hauwer et al. 1998, Hollande et al. 2001, Kermorgant \& Lehy 2001, Bierkamp et al. 2002, Kirton et al. 2002, Wroblewski et al. 2002). On the basis of binding and molecular biological studies, two high-affinity receptors for gastrin and the related peptide hormone cholecystokinin (CCK) have been characterised and cloned (Ito et al. 1993, Lee et al. 1993, Ulrich et al. 1993). Although the CCK-1 and CCK-2 receptors both belong to the family of G-coupled receptors and share $50 \%$ sequence homology, they can be distinguished using selective agonists and antagonists (Noble et al. 1999).

In the last decade progastrin processing intermediates such as Ggly and progastrin itself have been found by several laboratories to be biologically active (Seva et al.1994, Hollande et al. 1997, Baldwin et al. 2001b, Hollande et al. 2001). For instance Ggly and progastrin stimulate colonic proliferation and accelerate the development of colorectal cancers in transgenic mouse models (Singh et al. 2000, Koh et al. 2001), modulate migration in gastrointestinal cell lines (Hollande et al. 2001, Kermorgant 


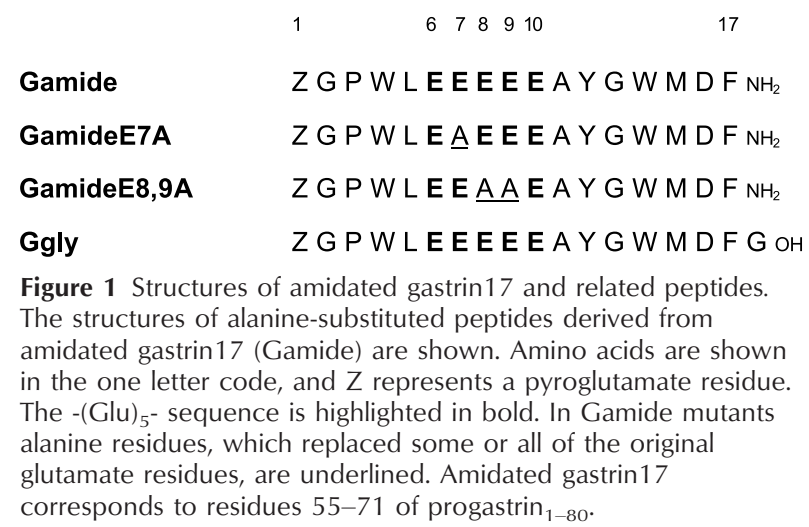

\& Lehy 2001), and are elevated in patients with colorectal cancer (Ciccotosto et al. 1995). These observations demonstrate important physiological and pathological roles for non-amidated forms of gastrin. Although a new gastrin binding site which bound both amidated and glycineextended gastrins with low affinity has been described (Baldwin 1995b), no high-affinity Ggly receptor has yet been cloned.

We recently demonstrated by fluorescence quenching that gastrins bind two ferric ions with high affinity in aqueous solution (Baldwin et al. 2001a). The nuclear magnetic resonance (NMR) spectral changes following the addition of one or two equivalents of ferric ions to Ggly solutions indicated that Glu7 acts as a ligand at the first ferric ion binding site, and that Glu8 and Glu9 act as ligands at the second ferric ion binding site (Pannequin et al. 2002). The ligand identification was confirmed by monitoring the fluorescence changes on addition of ferric ions to Ggly mutants with substitutions of alanine for one or more of the glutamates. The complete lack of activity in both proliferation and migration assays of a Ggly mutant in which Glu7 was replaced by Ala (GglyE7A), and the inhibition of Ggly activity by the iron chelator desferrioxamine (DFO), were consistent with the hypothesis that ferric ion binding is essential for biological activity. The significant $(60 \%)$ reduction in the ability of Gamide to stimulate proliferation in IMGE gastric cells incubated for $72 \mathrm{~h}$ in the presence of DFO suggested that binding of ferric ions might also contribute to the activity of amidated gastrins (Pannequin et al. 2002).

The aim of the present work was to define the role of ferric ion binding in the biological activity of Gamide. The involvement of Glu7, Glu8 and Glu9 in ferric ion binding to Gamide was first determined by fluorescence spectroscopy. The affinities for the CCK-2 receptor of Gamide, and Gamide mutants with substitutions of alanine for one or more of the glutamates (Fig. 1), were then compared. The abilities of the mutant peptides to stimulate both proliferation in T-lymphoblastoid Jurkat cells which express the CCK-2 receptor, and inositol phos- phate production in COS-7 cells transiently transfected with the CCK-2 receptor, were also investigated. We report that Glu7, Glu8 and Glu9 of Gamide are critical for binding ferric ions. However, the observation that the mutant peptides were as active as Gamide in all assays indicates that ferric ion binding is not required for the biological activity of amidated gastrins.

\section{Materials and Methods}

\section{Chemicals and cell lines}

Gamide and Gamide mutants were synthesised by Bachem (Bubendorf, Switzerland) and Auspep (Melbourne, Australia) respectively. Peptide concentrations were calculated from their absorbance at $280 \mathrm{~nm}$ as described previously (Baldwin et al. 2001a).

COS-7 cells were grown in $175 \mathrm{~cm}^{2}$ culture flasks in Dulbecco's modified Eagle's medium (DMEM) containing $10 \%$ fetal bovine serum (FBS), $100 \mathrm{U} / \mathrm{ml}$ penicillin and $100 \mu \mathrm{g} / \mathrm{ml}$ streptomycin at $37^{\circ} \mathrm{C}$.

The T-lymphoblastoid cell line Jurkat (Dornand et al. 1995) (kindly provided by Dr C Oiry, Université de Montpellier I, Montpellier, France) was grown at $37^{\circ} \mathrm{C}$ in RPMI 1640 medium containing 8\% FBS, $100 \mathrm{U} / \mathrm{ml}$ penicillin and $100 \mu \mathrm{g} / \mathrm{ml}$ streptomycin.

\section{Fluorescence spectroscopy}

The tryptophan fluorescence of peptide solutions was measured in $3 \mathrm{ml}$ quartz cuvettes thermostatted at $25^{\circ} \mathrm{C}$, with a Spex Fluorolog- $\tau 2$ spectrofluorimeter (Spex Industries, Edison, NJ, USA), with the excitation and emission wavelengths set at 290 and $345 \mathrm{~nm}$ respectively (Baldwin et al. 2001a). The quenching of tryptophan fluorescence induced by the binding of metal ions was used to calculate the fraction of binding sites occupied, $f_{a}$ :

$f_{\mathrm{a}}=\left(y_{\mathrm{f}}-\gamma\right) /\left(y_{\mathrm{f}}-y_{\mathrm{b}}\right)$

where $y$ is the fluorescence signal at a given concentration of metal ions, and $y_{\mathrm{b}}$ and $y_{\mathrm{f}}$ are the signals when the binding sites are fully occupied and unoccupied respectively (Baldwin et al. 2001a). The stoichiometry, $p$, and apparent dissociation constant, $K_{\mathrm{d}}$, were then obtained, using the program Sigmaplot (Jandel Scientific, San Rafael, CA, USA), from the intercept and slope of a linear regression of the data transformed in terms of the equation

$$
C_{\mathrm{s}} / f_{\mathrm{a}}=p C_{\mathrm{a}}+K_{\mathrm{d}} /\left(1-f_{\mathrm{a}}\right)
$$

where $C_{\mathrm{s}}$ is the total concentration of metal ions and $C_{\mathrm{a}}$ is the total concentration of amidated gastrin17 (Winzor \& Sawyer 1995).

\section{Transient transfection of COS-7 cells}

COS-7 cells were transiently transfected by the diethylaminoethyl (DEAE)-dextran method as described 
previously (Mantamadiotis \& Baldwin 1994). One day before transfection, $7 \times 10^{5}$ COS-7 cells were seeded into $10 \mathrm{~cm}$ plates in DMEM containing 10\% FBS and antibiotics, and grown in $5 \% \mathrm{CO}_{2}$ such that on the day of transfection the cells were $60 \%$ confluent. On the day of transfection, a DNA/DEAE-dextran solution was prepared by dropwise addition of $0.5 \mathrm{ml} 2 \mathrm{mg} / \mathrm{ml}$ DEAEdextran in PBS to $0.5 \mathrm{ml} 0.1 \%$ glucose in PBS containing $0 \cdot 5-2 \cdot 5 \mu \mathrm{g} / \mathrm{ml} \mathrm{pRFE}$ Neo plasmid DNA encoding the human CCK-2 receptor (Kennedy et al. 1995). The
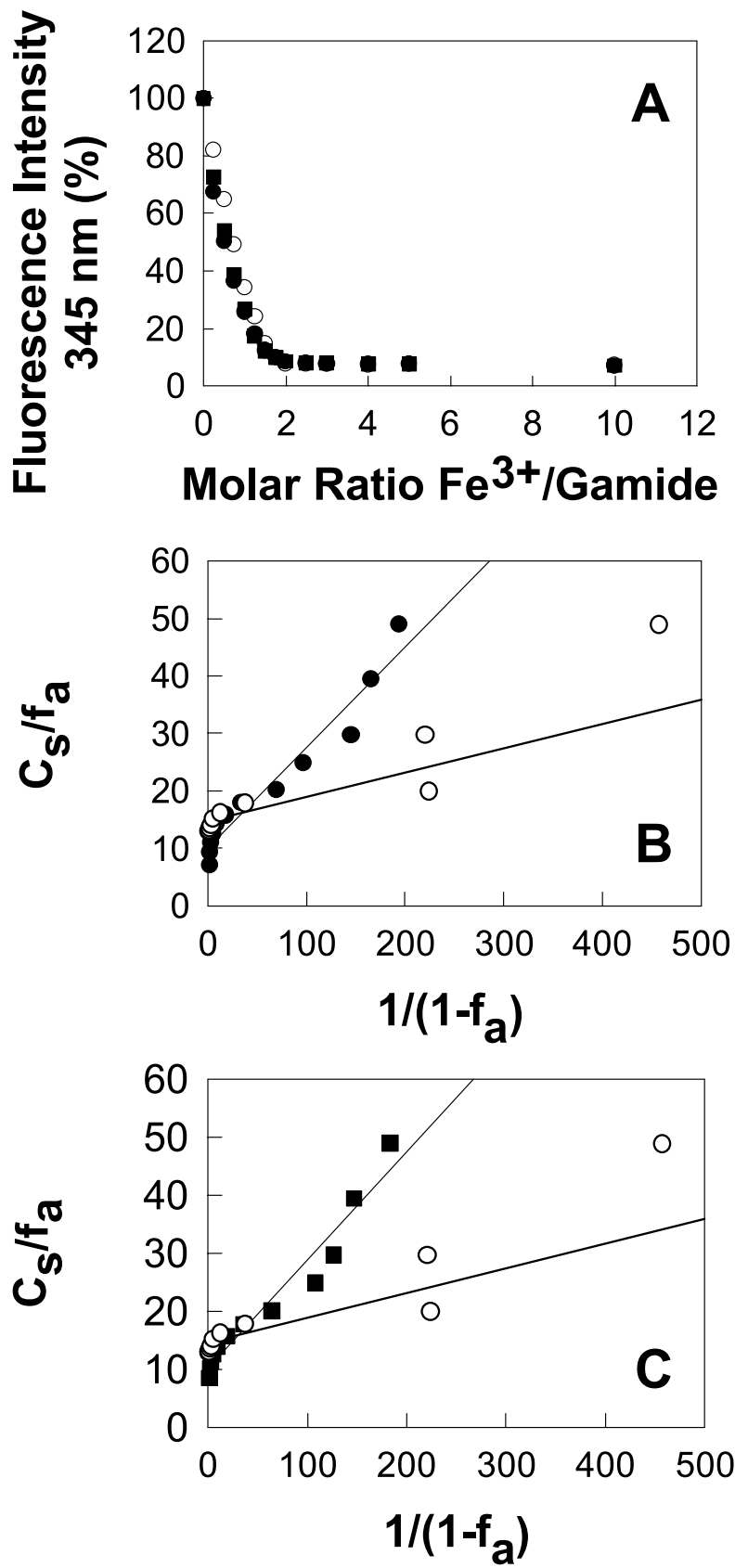

Table 1 Stoichiometry and affinity of ferric ion binding by amidated gastrin 17 and related peptides. The tryptophan fluorescence of amidated gastrin 17 and related peptides was measured in the presence of increasing concentrations of ferric ions at $\mathrm{pH} 4 \cdot 0$ (Baldwin et al. 2001a). Values of the stoichiometry and the apparent dissociation constant $\left(K_{\mathrm{d}}\right)$ were obtained from linear transformations of the data presented in Fig. 2A by least squares fitting. Values from the indicated number of independent experiments were combined to obtain the mean values ( \pm S.E.) presented below. The values previously reported (Pannequin et al. 2002) for Ggly are included for comparison

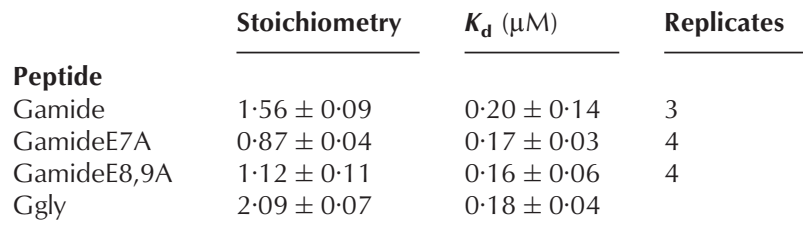

medium was aspirated and the cells were washed twice with PBS containing $0 \cdot 1 \%$ glucose, and gently rocked at $37^{\circ} \mathrm{C}$ for $20 \mathrm{~min}$ in the DNA/DEAE-dextran solution. The solution was then aspirated carefully, and replaced with $10 \mathrm{ml} 100 \mu \mathrm{M}$ chloroquine, and the cells were incubated at $37^{\circ} \mathrm{C}$ for $3 \mathrm{~h}$. After incubation, the solution was aspirated and the cells were washed twice with serum-free DMEM and grown overnight in DMEM containing $10 \%$ FBS and antibiotics. On the next day, the transfected cells were detached with $0 \cdot 25 \%$ trypsin $/ 0 \cdot 02 \%$ EDTA, re-plated onto a 24-well dish (25 000-100 000 cells/well) and grown for a further $24 \mathrm{~h}$ prior to the receptor binding or inositol phosphate assay.

\section{CCK-2 receptor binding}

Binding of Gamide, GamideE7A, and GamideE8,9A to the human CCK-2 receptor on transfected COS-7 cells was measured in triplicate by competition for ${ }^{125}$ I-Bolton and Hunter-labelled CCK-8 ( $\left.{ }^{125} \mathrm{I}-\mathrm{BH}-\mathrm{CCK}_{8}\right)$ binding (Kopin et al. 1992). Transfected COS-7 cells were grown to $60-70 \%$ confluence as described above, washed once

Figure 2 Glutamate residue 7 acts as a metal ion ligand. The quenching by ferric ions of the tryptophan fluorescence (A) of Gamide-derived peptides with single or double alanine substitutions was measured as described in Materials and Methods. The peptides were as follows: Gamide ( $\bigcirc)$, GamideE7A ( ), GglyE8,9A (ם). The buffer was $10 \mathrm{mM}$ sodium acetate, $\mathrm{pH}$ $4 \cdot 0$, containing $100 \mathrm{mM} \mathrm{NaCl}$ and $0.005 \%$ Tween 20. Values of the stoichiometry and the apparent dissociation constant were obtained from the intercept and slope respectively of linear transformations of the data for peptides with single (B) or double (C) alanine substitutions by least squares fitting with the program Sigmastat. The values of at least three independent experiments were combined to obtain the mean values presented in Table 1. Substitution of the glutamate(s) at position 7 , or at positions 8 and 9, of Gamide resulted in a reduction of one in the number of bound ferric ions. 
with PBS, and then incubated for $1 \mathrm{~h}$ at $37^{\circ} \mathrm{C}$ in $500 \mu \mathrm{l}$ DMEM containing $0 \cdot 1 \%$ BSA and ${ }^{125} \mathrm{I}-\mathrm{BH}-\mathrm{CCK}-8$ (100 000 c.p.m., 14.5 fmol, Amersham), in the presence and absence of peptide competitor. Cells were then washed twice with PBS containing 2\% BSA and lysed with $1 \mathrm{ml} 0.1 \mathrm{M} \mathrm{NaOH}$. Lysates were counted in a $\gamma-$ counter (LKB-Wallac, Turku, Finland) at 77\% efficiency.

Binding of Gamide, GamideE7A and GamideE8,9A to the human CCK-2 receptor on Jurkat cells was measured in triplicate by competition for ${ }^{125} \mathrm{I}-\mathrm{BH}-\mathrm{CCK}_{8}$ binding as described above. Jurkat cells were grown as described above, harvested by centrifugation at $1200 \mathrm{~g}$ for $5 \mathrm{~min}$,

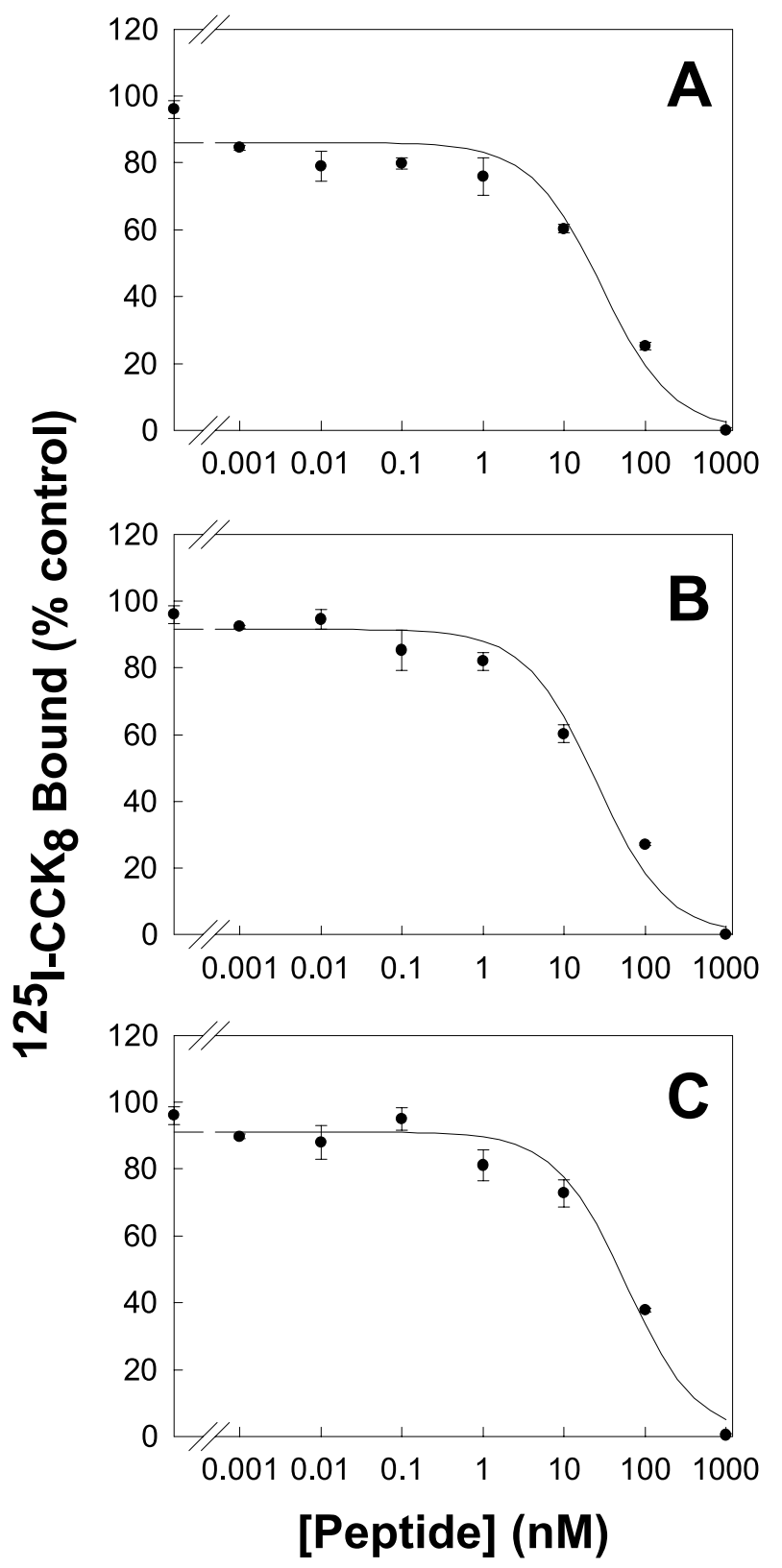

and re-suspended in PBS containing 0.2\% BSA. Cells $\left(1 \times 10^{6}\right.$ cells $/ 400 \mu$ l per tube $)$ were incubated with ${ }^{125} \mathrm{I}-$ $\mathrm{BH}-\mathrm{CCK}_{8}$ in the presence or absence of peptide competitor for $1 \mathrm{~h}$ at $37^{\circ} \mathrm{C}$. The binding reaction was terminated by addition of $2 \mathrm{ml} /$ tube of ice-cold PBS containing $2 \%$ BSA followed by centrifugation at $3000 \mathrm{~g}$ for $10 \mathrm{~min}$. The pellets were counted in a $\gamma$-counter.

Estimates of the concentration giving 50\% inhibition $\left(\mathrm{IC}_{50}\right)$, and of the levels of ${ }^{125} \mathrm{I}-\mathrm{BH}-\mathrm{CCK}_{8}$ bound in the absence of competitor, were obtained by nonlinear regression with Sigmaplot to the equation

$y=a /(1+x / b)$

where $y$ is the binding expressed as a percentage of the value $a$ observed in the absence of peptide competitor, $x$ is the concentration of peptide competitor, and $b$ is the $\mathrm{IC}_{50}$ value.

\section{Proliferation experiments}

Cell proliferation was measured by counting. Jurkat cells were grown in RPMI 1640 without FBS for $24 \mathrm{~h}$ and subsequently seeded into 96-well plates at a concentration of $5 \times 10^{4}$ cells/ $200 \mu \mathrm{l}$, in media containing $2 \% \mathrm{FBS}$. At the same time the test compounds were added at $100 \mathrm{nM}$ concentration. After incubation for $48 \mathrm{~h}$ at $37{ }^{\circ} \mathrm{C}$ the cells were stained with trypan blue $(0 \cdot 4 \%)$, and live cells were counted using a haemocytometer.

\section{Measurement of inositol phosphate production}

Intracellular inositol phosphate production was determined as described previously (Qian et al. 1995). CCK-2 receptor-transfected COS-7 cells $\left(10^{5}\right.$ cells $\left./ \mathrm{ml}\right)$ were plated in 24-multiwell culture plates in DMEM supplemented with $10 \% \mathrm{FBS}, 200 \mathrm{U} / \mathrm{ml}$ penicillin and $200 \mathrm{mg} / \mathrm{ml}$ streptomycin; 24 h later, cells were incubated overnight at $37^{\circ} \mathrm{C}$ with $5 \% \mathrm{CO}_{2}$ in $0.5 \mathrm{ml}$ DMEM supplemented with antibiotics and myo- $\left[2-{ }^{3} \mathrm{H}\right]$ inositol

Figure 3 Glu7, Glu8 and Glu9 are not essential for binding of Gamide to the CCK-2 receptor on transfected COS-7 cells. The ability of increasing concentrations of Gamide (A), GamideE7A (B) and Gamide E8,9A (C) to compete with ${ }^{125} \mathrm{I}-\mathrm{BH}^{-\mathrm{CCK}_{8}}$ (150 pM, 100000 c.p.m.) for binding to the human CCK-2 receptor on transiently transfected COS-7 cells was measured as described in Materials and Methods. Points are the means \pm S.E. of triplicates, expressed as a percentage of the value obtained in the absence of peptide competitor. The lines of best fit were obtained by nonlinear regression to a single site model with the program Sigmaplot. The values for $\mathrm{IC}_{50}$ and for the predicted ordinate intercept were as follows: Gamide, $29 \mathrm{nM}, 86.1 \%$; GamideE7A, $25 \mathrm{nM}, 91 \cdot 6 \%$; GamideE8,9A, 58 nM, 91.0\%. These values were combined with the data from at least two other experiments to obtain the mean values presented in Table 2. Substitution of the glutamates at position 7, or at positions 8 and 9, of Gamide did not significantly reduce the affinity of binding to the human CCK-2 receptor on transiently transfected COS-7 cells. 
Table 2 Affinity of amidated gastrin 17 and related peptides for the CCK-2 receptor. Binding of ${ }^{125}$ I-BH-CCK 8 to COS-7 cells transiently transfected with the CCK-2 receptor, or to Jurkat cells, was measured in displacement experiments with increasing concentrations of Gamide or related peptides as described in Fig. 3 legend. Values of the percentage maximum binding in the absence of competitor and of the $\mathrm{IC}_{50}$ were obtained from the data presented in Fig. 3 by least squares fitting with the program Sigmaplot. Values from the indicated number of independent experiments were combined to obtain the mean values ( \pm S.E.) presented below. Data were analysed by one-way ANOVA. If there was a statistically significant difference in the data set, individual values were compared with the Gamide value by Student's t-test with Bonferroni correction

\section{COS-7}

\% Maximum
$94 \cdot 2 \pm 2 \cdot 4$
$92 \cdot 0 \pm 1 \cdot 0$
$98 \cdot 4 \pm 2 \cdot 1$

Peptide

Gamide

GamideE7A

GamideE8,9A

$$
\begin{aligned}
& 27 \pm 7 \\
& 37 \pm 11
\end{aligned}
$$

$112 \pm 39$

\begin{tabular}{|c|c|c|c|}
\hline$\%$ Maximum binding & $\mathrm{IC}_{50}(\mathrm{nM})$ & Replicates & $P$ \\
\hline $100 \cdot 0 \pm 3 \cdot 1$ & $1 \cdot 3 \pm 0 \cdot 2$ & 6 & - \\
\hline $96 \cdot 7 \pm 4 \cdot 6$ & $3 \cdot 1 \pm 0 \cdot 2$ & 3 & 0.005 \\
\hline $97 \cdot 8 \pm 9 \cdot 0$ & $2 \cdot 8 \pm 0 \cdot 5$ & 3 & $0 \cdot 017$ \\
\hline
\end{tabular}

Jurkat
(2.5 $\mu \mathrm{Ci}$ /well). Cells were then washed with pre-warmed DMEM and incubated $\left(30 \mathrm{~min}, 37^{\circ} \mathrm{C}\right)$ with DMEM supplemented with $20 \mathrm{mM} \mathrm{LiCl}$. Loaded cells were then washed in $1 \mathrm{ml}$ inositol phosphate buffer $(135 \mathrm{mM} \mathrm{NaCl}$, $20 \mathrm{mM}$ HEPES, $2 \mathrm{mM} \mathrm{CaCl}_{2}, 1.2 \mathrm{mM} \mathrm{MgSO}_{4}, 1 \mathrm{mM}$ EGTA, $10 \mathrm{mM} \mathrm{LiCl,} \mathrm{0.5 \%} \mathrm{BSA,} \mathrm{pH} \mathrm{7.45)} \mathrm{and} \mathrm{incubated}$ with or without agonist in $0.5 \mathrm{ml}$ of the same buffer. After $1 \mathrm{~h}$ at $37^{\circ} \mathrm{C}$, the reaction was stopped by removing the incubation medium and adding $1 \mathrm{ml}$ ethanol/ $\mathrm{HCl}$ (2000:1, v/v). The solution was applied to a column containing $0.8 \mathrm{ml}$ Dowex AG-1-X8 anion exchange resin, which had been previously equilibrated with Milli-Q water. The columns were washed with $4 \mathrm{ml}$ Milli-Q water, followed by $4 \mathrm{ml} 40 \mathrm{mM}$ ammonium formate, and inositol phosphates were eluted with $4 \mathrm{ml} 1 \mathrm{M}$ ammonium formate. The radioactivity of each eluate was determined in a Packard Tri-Carb 2100TR liquid scintillation analyser after addition of complete phase-combining solution (Amersham). For the positive control, transfected COS-7 cells were incubated with $\mathrm{AlF}_{4}{ }^{-}$prepared by combining $30 \mathrm{mM} \mathrm{NaF}$ and $10 \mu \mathrm{M} \mathrm{AlCl} \mathrm{Al}_{3}$ under the same experimental conditions.

\section{Statistics}

Results are expressed as the means \pm S.E. Data were analysed by one-way ANOVA. If there was a statistically significant difference in the data set, individual values were compared with the control by $t$-test with Bonferroni correction for multiple analyses. Differences with $P$ values of $<0 \cdot 05$ were considered significant.

\section{Results}

We have reported previously that both Ggly and Gamide bound two ferric ions in aqueous solution at $\mathrm{pH} 4 \cdot 0$, with an apparent $K_{\mathrm{d}}$ of $0.6 \mu \mathrm{M}$ (Baldwin et al. 2001a). Investigation of the effect of ferric ions on the Ggly NMR spectrum indicated that Glu7 was acting as one of the ligands for the first ferric ion binding site, and that Glu8 and Glu9 were acting as ligands for the second ferric ion binding site (Pannequin et al. 2002). This observation was confirmed by examination of the ability of ferric ions to quench the fluorescence of mutant Ggly peptides in which some or all of the glutamates had been replaced by alanines. For example, replacement of Glu7 with Ala reduced the stoichiometry of ferric ion binding by 1 without greatly changing the apparent affinity (Pannequin et al. 2002).

\section{Definition of ferric ion ligands}

In order to confirm that Glu7, Glu8 and Glu9 were also involved in ferric ion binding to Gamide, we first investigated the ability of ferric ions to quench the fluorescence of mutant Gamide peptides in which Glu7, or Glu8 and Glu9, had been replaced by alanines. A pH value of $4 \cdot 0$ was selected for these experiments to permit direct comparison with previous data on Ggly (Baldwin et al. 2001a) and mutant Ggly peptides (Pannequin et al. 2002). This value was originally chosen to avoid problems with the precipitation of ferric hydroxides at $\mathrm{pH}>4 \cdot 0$ (Baldwin et al. 2001a). As with Ggly, replacement of Glu7 with Ala reduced the stoichiometry of ferric ion binding by 1 without greatly changing the apparent affinity (Fig. 2, Table 1). The importance of Glu8 and Glu9 in binding the second ferric ion was confirmed by the similar reduction in stoichiometry observed with a mutant Gamide peptide in which Glu8 and Glu9 had both been replaced by alanines (Fig. 2, Table 1).

\section{Role of glutamates in CCK-2 receptor binding}

In order to determine the importance of Glu7, Glu8 and Glu9 in the binding of Gamide to the CCK-2 receptor, the two mutant peptides GamideE7A and Gamide E8,9A were tested for their ability to bind to COS-7 cells transiently transfected with CCK-2 receptor cDNA. Both 


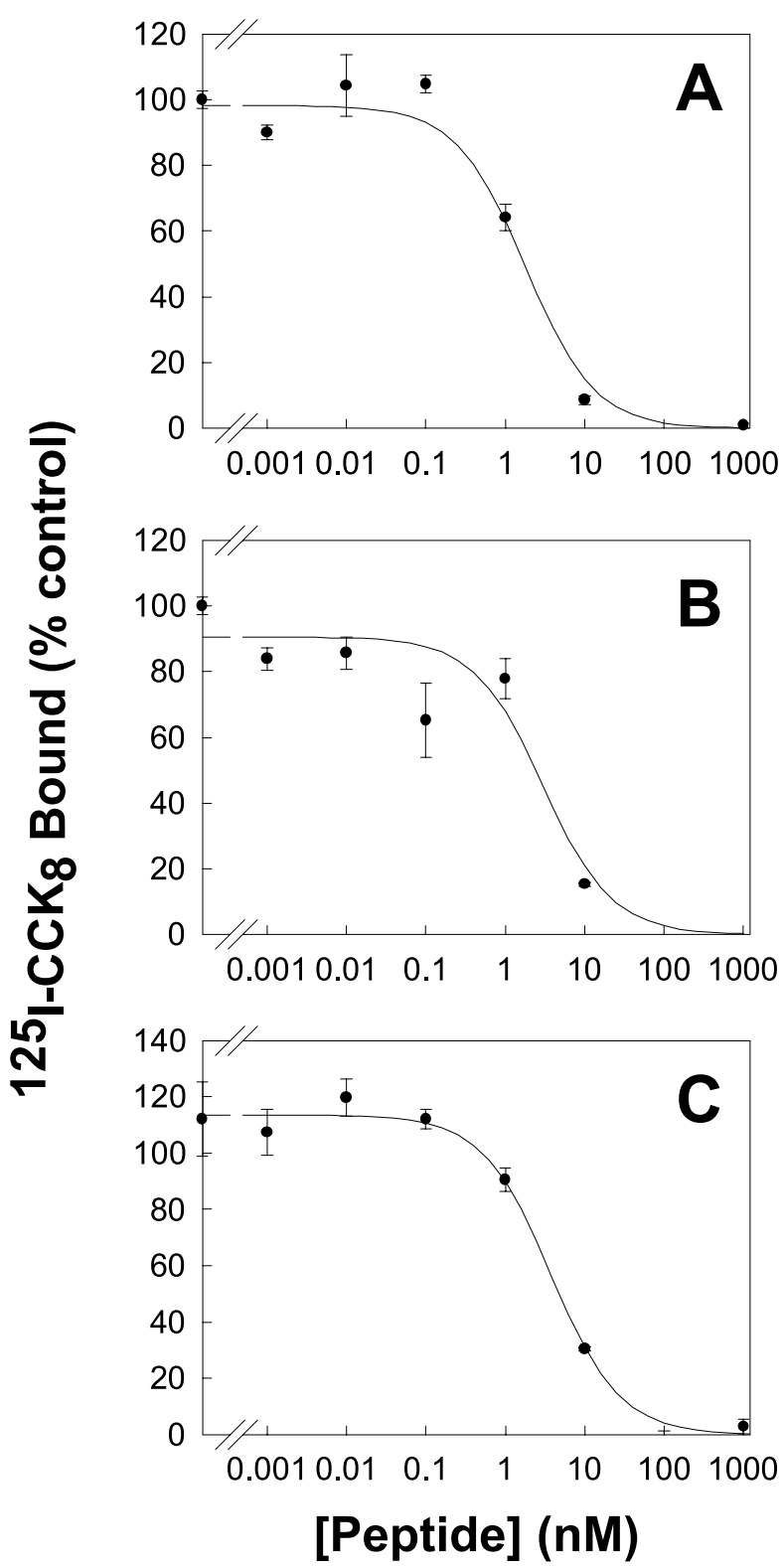

Figure 4 Glu7, Glu8 and Glu9 are not essential for binding of Gamide to the CCK-2 receptor on Jurkat cells. The ability of increasing concentrations of Gamide (A), GamideE7A (B), and GamideE8,9A (C) to compete with ${ }^{125} \mathrm{I}-\mathrm{BH}^{-\mathrm{CCK}_{8}}$ (150 pM, 100000 c.p.m.) for binding to the human CCK-2 receptor on Jurkat cells was measured as described in Materials and Methods. Points are the means \pm S.E. of triplicates, expressed as a percentage of the value obtained in the absence of peptide competitor. The lines of best fit were obtained by nonlinear regression to a single site model with the program Sigmaplot. The values for $\mathrm{IC}_{50}$ and for the predicted ordinate intercept were as follows: Gamide, 1.8 nM, 98.2\%; GamideE7A, 3.0 nM, 90.6\%; GamideE8,9A, 3.8 nM, $113 \cdot 6 \%$. These values were combined with the data from at least two other experiments to obtain the mean values presented in Table 2. Substitution of the glutamates at position 7 , or at positions 8 and 9, of Gamide significantly reduced the affinity of binding to the human CCK-2 receptor on Jurkat cells.

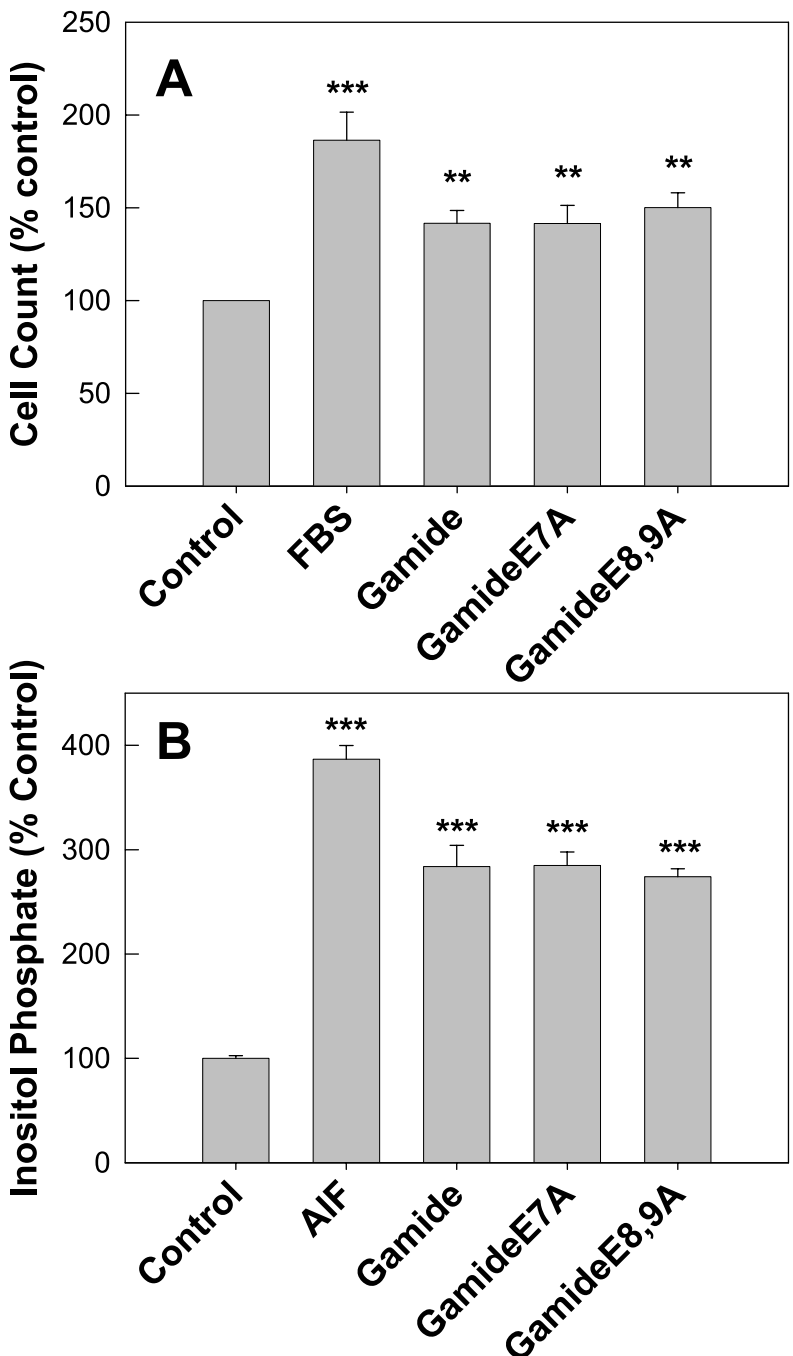

Figure 5 Glu7, Glu8 and Glu9 are not essential for Gamide-induced biological activity. The effect of $100 \mathrm{nM}$ Gamide, GamideE7A, or GamideE8,9A on proliferation of Jurkat cells (A), or of $10 \mathrm{nM}$ Gamide, GamideE7A, or GamideE8,9A on inositol phosphate production (B) in COS-7 cells transiently transfected with the human CCK-2 receptor, was measured as described in Materials and Methods. (A) Means \pm S.E. from three independent experiments, each performed in triplicate. (B) Means \pm S.E. of triplicates, and similar results were obtained in three independent experiments. All data are expressed as a percentage of the value obtained in the absence of stimulation. The effect of $10 \%$ FBS (A) or $10 \mu \mathrm{M} \mathrm{AlF}_{4}{ }^{-}$(AIF) (B) was determined as a positive control. Statistical significance relative to the untreated control $\left({ }^{* *}, P<0 \cdot 01 ;{ }^{* * *}, P<0 \cdot 001\right)$ was assessed by one-way ANOVA, followed by $t$-test with Bonferroni correction. No significant difference was observed in the extent of stimulation by Gamide, GamideE7A or GamideE8,9A.

peptides retained the ability to compete with ${ }^{125} \mathrm{I}-\mathrm{BH}-$ $\mathrm{CCK}_{8}$, and their affinities for the CCK-2 receptor were not significantly lower than the affinity of Gamide (Fig. 3, Table 2). Because the affinity of Gamide 
$\left(\mathrm{IC}_{50}=27 \pm 7 \mathrm{nM}\right.$; Table 2) was itself lower than values previously reported for COS-7 cells $\left(\mathrm{IC}_{50}=0.94 \mathrm{nM}\right.$, Ulrich et al. 1993; $\mathrm{IC}_{50}=6.4 \mathrm{nM}$, Kopin et al. 1992), the same experiments were repeated with the T-lymphoblastoid cell line Jurkat, which has previously been demonstrated to express CCK-2 receptors
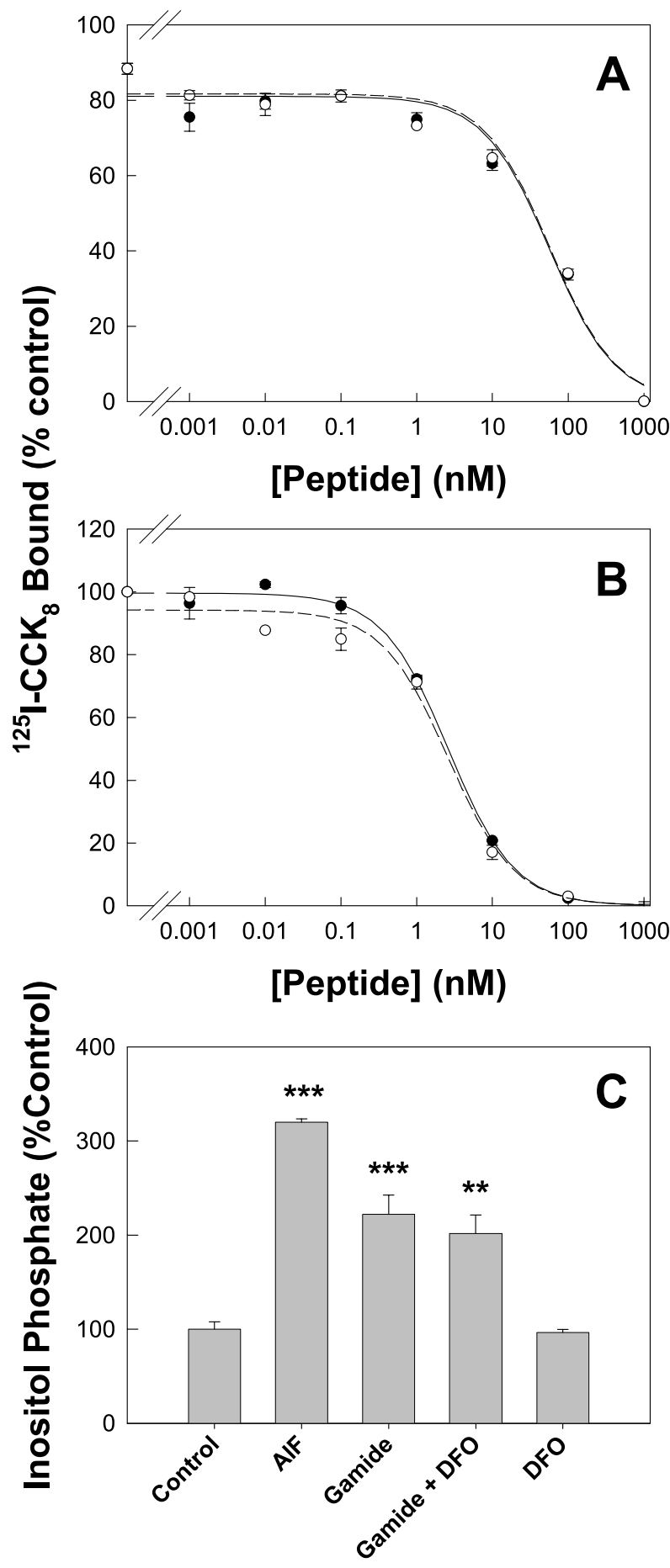

$\left(\mathrm{IC}_{50}=1 \cdot 05 \mathrm{nM}\right.$, Dornand et al. 1995). The affinities of all peptides for the CCK-2 receptor on Jurkat cells were approximately 10 - to 20 -fold higher than for the receptor on COS-7 cells. In this case the affinities of the mutant peptides for the CCK-2 receptor were slightly but significantly lower than the affinity of Gamide for the receptor (Fig. 4, Table 2).

\section{Role of glutamates in biological activity}

We then investigated the role of the individual glutamates in biological activity. The effects of the mutants GamideE7A and GamideE8,9A (see Fig. 1 for sequences) on proliferation of Jurkat cells were compared (Fig. 5A). The effects of the mutants GamideE7A and GamideE8,9A on inositol phosphate production in COS-7 cells transiently transfected with the CCK-2 receptor were also compared (Fig. 5B). The observation that GamideE7A and GamideE8,9A were both as active as Gamide indicated that Glu7 did not play a critical role in Gamide-stimulated inositol phosphate production.

\section{Role of ferric ions in CCK-2 receptor binding and biological activity}

In order to confirm that the binding of ferric ions to Glu7, Glu8 and Glu9 did not affect the binding of Gamide to the CCK-2 receptor, the ability of the iron chelating agent DFO to interfere with the binding of ${ }^{125} \mathrm{I}-\mathrm{BH}-\mathrm{CCK}_{8}$ to the CCK-2 receptor was investigated. No significant difference in the $\mathrm{IC}_{50}$ value for Gamide binding to the CCK-2 receptor in transiently transfected COS cells

Figure 6 Ferric ions are not essential for binding of Gamide to the CCK-2 receptor or for Gamide-induced inositol phosphate production. The ability of increasing concentrations of Gamide to compete with ${ }^{125} \mathrm{I}-\mathrm{BH}-\mathrm{CCK}_{8}(150$ pM, 100000 c.p.m.) for binding to the human CCK-2 receptor on (A) transiently transfected COS-7 cells or $(B)$ Jurkat cells in the presence $(O)$ and absence (-) of $1 \mu \mathrm{M}$ DFO was measured as described in Fig. 3 legend. The values for $\mathrm{IC}_{50}$ and for the ordinate intercept used to construct the indicated lines of best fit were as follows: (A) Gamide (continuous line), $57 \mathrm{nM}, 81 \cdot 1 \%$; Gamide DFO (dashed line), $58 \mathrm{nM}, 81 \cdot 7 \%$. (B) Gamide (continuous line), $2 \cdot 6 \mathrm{nM}, 99 \cdot 6 \%$; Gamide DFO (dashed line), $2.6 \mathrm{nM}, 94 \cdot 3 \%$. These values were combined with the data from at least two other experiments to obtain the mean values presented in Table 3. The iron chelator DFO did not significantly reduce the affinity of the human CCK-2 receptor on transiently transfected COS-7 cells or on Jurkat cells for Gamide. (C) The effect of $10 \mu \mathrm{M} \mathrm{AlF}_{4}{ }^{-}$(AIF) or $10 \mathrm{nM}$ Gamide in the presence and absence of $1 \mu \mathrm{M}$ DFO, on inositol phosphate production in COS-7 cells transiently transfected with the human CCK-2 receptor was measured as described in Fig. 5 legend. Statistical significance relative to the untreated control $(* *, P<0.01$; ***, $P<0 \cdot 001)$ was assessed by one-way analysis of variance, followed by $t$-test with Bonferroni correction. No significant difference was observed in the extent of stimulation by Gamide in the presence and absence of the iron chelator DFO. Similar results were obtained in three independent experiments. 
Table 3 Effect of DFO on the affinity of amidated gastrin 17 for the CCK-2 receptor. Binding of ${ }^{125}{ }^{-B H}-\mathrm{CCK}_{8}$ to $\mathrm{COS}_{-} 7$ cells transiently transfected with the CCK-2 receptor, or to Jurkat cells, was measured in displacement experiments with increasing concentrations of Gamide in the presence and absence of $1 \mu \mathrm{M}$ DFO as described in Fig. 6 legend. For COS-7 cells, values ( \pm s.E.) of the percentage maximum binding in the absence of competitor and of the $\mathrm{IC}_{50}$ were obtained from the data presented in Fig. 6 by least squares fitting with the program Sigmaplot, and are thus based on eight data points, each in duplicate. For Jurkat cells, values from the indicated number of independent experiments were combined to obtain the mean values ( \pm S.E.). Data were analysed by Student's $t$-test

\section{COS-7}

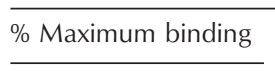

Peptide

Gamide

Gamide+DFO

\section{$81 \cdot 1 \pm 1 \cdot 7$}

$81 \cdot 7 \pm 1 \cdot 6$

$\underline{\mathrm{IC}_{50}(\mathrm{nM})} \underline{\text { Replicates }} \stackrel{P}{ }$

$57 \pm 11$

$58 \pm 11$
Jurkat

\begin{tabular}{|c|c|c|c|}
\hline$\%$ Maximum binding & $\mathrm{IC}_{50}(\mathrm{nM})$ & Replicates & $P$ \\
\hline $99 \cdot 0 \pm 0 \cdot 4$ & $3 \cdot 3 \pm 0 \cdot 8$ & 3 & 一 \\
\hline $96 \cdot 0 \pm 1 \cdot 2$ & $3 \cdot 6 \pm 0 \cdot 9$ & 3 & NS \\
\hline
\end{tabular}

(Fig. 6A) or in Jurkat cells (Fig. 6B) was observed in the presence and absence of DFO (Table 3).

We also investigated the effect of the iron chelator DFO on the biological activity of gastrins. DFO had no effect on Gamide-stimulated inositol phosphate production in COS-7 cells transiently transfected with the CCK-2 receptor (Fig. 6C). We conclude that binding of ferric ions to Glu7, Glu8 and Glu9 is not essential for the biological activity of Gamide.

\section{Discussion}

We have previously demonstrated that Ggly binds two ferric ions selectively and with high affinity (Baldwin et al. 2001a). The first and second site ferric ion ligands were identified by NMR and fluorescence spectroscopy as Glu7, and Glu8 and Glu9 respectively (Pannequin et al. 2002). Binding of ferric ions was shown to be essential for the effects of Ggly on both cell proliferation and migration (Pannequin et al. 2002). The first aim of the work presented here was to locate the ferric ion binding sites within the Gamide sequence by fluorescence spectroscopy of mutant peptides in which some or all of the glutamates had been replaced by alanines. The second aim was to determine the role of ferric ion binding in the biological effects of Gamide. The results presented in this paper demonstrate for the first time that ferric ions bind to Glu7, Glu8 and Glu9 of Gamide, but reveal that in contrast to Ggly, ferric ion binding is not essential for the biological activity of Gamide.

Replacement of Glu7 with Ala reduced the stoichiometry of ferric ion binding from the value of 1.6 observed with Gamide to $0 \cdot 9$, without changing the apparent affinity (Table 1). The importance of glutamates 8 and 9 in binding the second ferric ion was confirmed by the similar reduction in stoichiometry observed with a peptide in which glutamates 8 and 9 had both been replaced by alanines. Sequence comparisons of gastrins across eight mammalian species are also consistent with an important role for Glu7, Glu8 and Glu9, since these three residues are strictly conserved with the exception of equine gastrin, which has Lys instead of Glu7 (Moore et al. 1997). In contrast, Glu10 is unlikely to play a functional role since in four species it is replaced by Ala (Moore et al. 1997).

Progastrin $_{6-80}$ also binds two ferric ions with similar affinity to Gamide and Ggly (Baldwin 2004). Equilibrium dialysis experiments with ${ }^{59} \mathrm{Fe}^{3+}$ showed that of four trivalent and seven divalent (including $\mathrm{Ca}$ and $\mathrm{Mg}$ ) metal ions, only ferric and ferrous ions were able to compete for ${ }^{59} \mathrm{Fe}^{3+}$ binding (Baldwin 2004). Although amidated gastrins have previously been shown to bind three $\mathrm{Ca}^{2+}$ or $\mathrm{Mg}^{2+}$ ions in organic solvents such as trifluoroethanol (Peggion $e$ al. 1983), the inability of $\mathrm{Ca}^{2+}$ ions to compete with ${ }^{59} \mathrm{Fe}^{3+}$ for the progastrin binding site was consistent with the failure to detect high-affinity $\mathrm{Ca}^{2+}$ binding to Gamide in aqueous solution (Torda et al. 1985). The high-affinity $\mathrm{Ca}^{2+}$ binding site in progastrin (Baldwin et al. $2001 b$ ) is presumably formed wholly or in part from residues 6-54 and 73-80, which are removed during processing to Gamide.

Mutation of Glu7, or Glu8 and Glu9, to Ala slightly decreased the affinity of Gamide for the CCK-2 receptor (Table 2). The ratio of $\mathrm{IC}_{50}$ GamideE7A/IC 50 Gamide was 1.4 for transfected COS-7 cells and $2 \cdot 4$ for T-lymphoblastoid Jurkat cells, but the difference was significant in the latter case only. Similarly the ratio of $\mathrm{IC}_{50}$ GamideE8,9A/IC I0 $_{50}$ Gamide was $4 \cdot 1$ for transfected COS-7 cells and $2 \cdot 2$ for T-lymphoblastoid Jurkat cells, and the difference was significant in the latter case only. We conclude that Glu7, Glu8 and Glu9 are not essential for binding of Gamide to the CCK-2 receptor. Furthermore, since Glu7, Glu8 and Glu9 have been defined as the ligands for ferric ion binding to Gamide, we conclude that binding of ferric ions is not essential for recognition of Gamide by the CCK-2 receptor. The 10 - to 40 -fold difference in the affinities measured in COS-7 cells and Jurkat cells may perhaps be explained by the greater amounts of CCK-2 receptor expressed in COS-7 cells. For example, there may be insufficient amounts of $G$ protein, 
or other intracellular protein coupled to the CCK-2 receptor, to convert all the CCK-2 receptor to the higher affinity form.

Comparison of the ability of Gamide mutants, in which one or more of the glutamates were replaced by alanine, to stimulate proliferation or inositol phosphate production revealed that Glu7, Glu8 and Glu9 were not essential for biological activity. In contrast, comparison of Ggly mutants, in which one or more of the glutamates were replaced by alanine, had previously demonstrated that Glu7 was essential for proliferation (Pannequin et al. 2002). Our results are consistent with previous data on the physiological properties of a series of synthetic peptides structurally related to Gamide (Tracy \& Gregory 1964), which indicated that only the $\mathrm{C}$-terminal tetrapeptide Trp-Met-Asp-Phe- $\mathrm{NH}_{2}$ was required for a range of physiological effects. These results have been confirmed in binding experiments with Gamide fragments and the cloned CCK-2 receptor (Kopin et al. 1992, Ito et al. 1993). However, residues $\mathrm{N}$-terminal to the tetrapeptide must contribute to the binding of Gamide to the CCK-2 receptor, since both potency in bioassays and affinity for the CCK-2 receptor increased with chain length. The observation that pentagastrin (tert-butoxycarbonyl- $\beta$-AlaTrp-Met-Asp-Phe-amide) is as potent as Gamide in vivo (Morley et al. 1965), suggests that the additional tertbutoxycarbonyl- $\beta$-Ala group of pentagastrin makes a contribution to the binding energy approximately equal to the contribution of the polyglutamate ferric ion binding region. Both contributions could arise from independent binding to different regions of the receptor. In the case of pentagastrin that contribution would be independent of ferric ions, but in the case of Gamide it could be either iron dependent or iron independent. The possible contribution of ferric ions had not been investigated prior to our work.

The results of experiments with the iron chelator DFO are consistent with the bioactivity and binding data for Gamide derivatives described in the previous paragraph. Thus, DFO had no effect on the affinity of Gamide for the CCK-2 receptor expressed on COS-7 cells (Fig. 6A) or on Jurkat cells (Fig. 6B), or on the ability of Gamide to stimulate inositol phosphate production in COS-7 cells (Fig. 6C). We were unable to determine the effect of DFO on the ability of Gamide to stimulate inositol phosphate production in IMGE cells because the maximum response to gastrins was only $110 \%$ of control in this cell line (Pannequin et al. 2004). Our present data with DFO confirm that the binding of ferric ions to Glu7, Glu8 and Glu9 of Gamide is not essential for CCK-2 receptor binding or biological activity.

This conclusion at first sight appears to conflict with our earlier report that DFO reduced Gamide-stimulated proliferation of the gastric cell line IMGE by 60\% (Pannequin et al. 2002). One possible explanation for this apparent discrepancy is that the proliferative response to Gamide was measured over a $72 \mathrm{~h}$ period, whereas the inositol phosphate assay used to assess the effect of DFO in the current report was for $1 \mathrm{~h}$ only. Kicic and coworkers (2001) have previously shown that the inhibition of cellular ferric ion uptake by DFO is time dependent, with little or no inhibition after $2 \mathrm{~h}$, and significant inhibition after $24 \mathrm{~h}$. We therefore postulate that proliferation involves a rate-limiting ferric ion-dependent step, such as cellular ferric ion uptake, which is not controlled by the CCK-2 receptor, and that this step is inhibited only after prolonged incubation with DFO. Further work to resolve this apparent discrepancy is underway.

In conclusion, the binding of ferric ions by Gamide has been investigated for the first time. Glu7, Glu8 and Glu9 have been shown to act as ligands at the two ferric ion binding sites. Investigation of the activity of Gamide mutants in proliferation and inositol phosphate assays revealed that Glu7, Glu8 and Glu9 are not essential for biological activity. Furthermore the observation that the iron chelator DFO did not inhibit binding of Gamide to the CCK-2 receptor or Gamide-stimulated inositol phosphate production confirmed that ferric ion binding is not essential for the biological activity of Gamide. The absence of any requirement for ferric ion binding to the $-(\mathrm{Glu})_{5^{-}}$ sequence for Gamide activity is in direct contrast to Ggly, the glutamates of which are essential for activity. The present work thus confirms that the mechanisms of action of the glycine-extended and amidated forms of the peptide hormone gastrin are distinct, and demonstrates for the first time a selective dependence of the glycine-extended form on the presence of ferric ions for bioactivity. Our findings reinforce the concept that Ggly should be considered a distinct bioactive end product rather than the precursor of the mature amidated form (Dockray et al. 2001).

These observations open several avenues for future investigation. As described previously the complex between ferric ions and gastrins may play a role in the uptake of ferric ions from the lumen of the gastrointestinal tract (Baldwin et al. 2001a). Alternatively formation of the complex between gastrins and ferric ions may increase the stability of gastrins in vivo, and hence modulate the duration of the biological response to gastrins. Furthermore the contrasting requirements for ferric ion binding between Ggly and Gamide are consistent with the hypothesis that the Ggly receptor and the CCK-2 receptor have quite different structures. Appropriate ferric ion chelation and competition strategies could therefore be developed for the selective inhibition of the biological activity of Ggly. For example, our observations with the ferric ion chelator DFO suggest that treatment of animals with DFO would abolish Ggly-, and reduce Gamide-, dependent proliferation in the colonic mucosa, but would not change Gamide-dependent acid secretion. Finally, two general principles emerge from the present work. First, amidation may dramatically alter both the site of action of a peptide and the nature of its physiological effect. Secondly, the differences in receptor binding between 
amidated and non-amidated peptides could be utilised to develop targeted antagonists.

\section{Funding}

This work was supported by grants 1RO1 GM065926-01 from the National Institutes of Health ( $G$ B, A S), A00103736 (G B) from the Australian Research Council 208926 (G B) and 114123 (A S) from the National Health and Medical Research Council of Australia, and by the Austin Hospital Medical Research Foundation (G B, A S). There is no conflict of interest that would prejudice the impartiality of the research described in this article.

\section{References}

Abou-Mohamed GA, Huang J, Oldham CD, Taylor TA, Jin L, Calwell RB, May SW \& Caldwell RW 2000 Vascular and endothelial actions of inhibitors of substance $\mathrm{P}$ amidation. Journal of Cardiovascular Pharmacology 35 871-880.

Baldwin GS 1995a The role of gastrin and cholecystokinin in normal and neoplastic gastrointestinal growth. Journal of Gastroenterology and Hepatology 10 215-232.

Baldwin GS $1995 b$ The $78 \mathrm{kDa}$ gastrin binding protein is a candidate receptor for autocrine progastrin. FEBS Letters 359 97-100.

Baldwin GS 2004 Properties of the complex between recombinant human progastrin and ferric ions. Protein Journal 23 65-70.

Baldwin GS, Curtain CC \& Sawyer WH 2001a Selective, high-affinity binding of ferric ions by glycine-extended gastrin(17). Biochemistry 40 10741-10746.

Baldwin GS, Hollande F, Yang Z, Karelina Y, Paterson A, Strang R, Fourmy D, Neumann G, \& Shulkes A $2001 b$ Biologically active recombinant human progastrin6-80 contains a tightly bound calcium ion. Journal of Biological Chemistry 276 7791-7796.

Bierkamp C, Kowalski-Chauvel A, Dehez S, Fourmy D, Pradayrol L \& Seva C 2002 Gastrin mediated cholecystokinin-2 receptor activation induces loss of cell adhesion and scattering in epithelial MDCK cells. Oncogene 21 7656-7670.

Ciccotosto GD, McLeish A, Hardy KJ \& Shulkes A 1995 Expression, processing, and secretion of gastrin in patients with colorectal carcinoma. Gastroenterology 109 1142-1153.

De Hauwer C, Camby I, Darro F, Migeotte I, Decaestecker C, Verbeek C, Danguy A, Pasteels JL, Brotchi J, Salmon I, Van Ham P \& Kiss R 1998 Gastrin inhibits motility, decreases cell death levels and increases proliferation in human glioblastoma cell lines. Journal of Neurobiology 37 373-382.

Dockray GJ 1999 Gastrin and gastric epithelial physiology. Journal of Physiology 518 315-324.

Dockray GJ, Varro A, Dimaline R \& Wang T 2001 The gastrins: their production and biological activities. Annual Review of Physiology 63 119-139.

Dornand J, Roche S, Michel F, Bali JP, Cabane S, Favero J \& Magous R 1995 Gastrin-CCK-B type receptors on human T lymphoblastoid Jurkat cells. American Journal of Physiology 268 G522-G529.

Hollande F, Imdahl A, Mantamadiotis T, Ciccotosto GD, Shulkes A \& Baldwin GS 1997 Glycine-extended gastrin acts as an autocrine growth factor in a nontransformed colon cell line. Gastroenterology 113 1576-1588.

Hollande F, Choquet A, Blanc EM, Lee DJ, Bali JP \& Baldwin GS 2001 Involvement of phosphatidylinositol 3-kinase and mitogen-activated protein kinases in glycine-extended gastrin-induced dissociation and migration of gastric epithelial cells. Journal of Biological Chemistry 276 40402-40410.
Ito M, Matsui T, Taniguchi T, Tsukamoto T, Murayama T, Arima N, Nakata H, Chiba T \& Chihara K 1993 Functional characterization of a human brain cholecystokinin-B receptor. A trophic effect of cholecystokinin and gastrin. Journal of Biological Chemistry 268 18300-18305.

Kennedy K, Escrieut C, Dufresne M, Clerc P, Vaysse N \& Fourmy D 1995 Identification of a region of the N-terminal of the human CCKA receptor essential for the high affinity interaction with agonist CCK. Biochemical and Biophysical Research Communications 213 845-852.

Kermorgant S \& Lehy T 2001 Glycine-extended gastrin promotes the invasiveness of human colon cancer cells. Biochemical and Biophysical Research Communications 285 136-141.

Kicic A, Chua AC \& Baker E 2001 Effect of iron chelators on proliferation and iron uptake in hepatoma cells. Cancer $\mathbf{9 2}$ 3093-3110.

Kirton CM, Wang T \& Dockray GJ 2002 Regulation of parietal cell migration by gastrin in the mouse. American Journal of Physiology 283 G787-G793.

Koh TJ, Dockray GJ, Varro A, Cahill RJ, Dangler CA, Fox JG \& Wang TC 2001 Overexpression of glycine-extended gastrin in transgenic mice results in increased colonic proliferation. Journal of Clinical Investigation 103 1119-1126.

Kopin AS, Lee Y-M, McBride EW, Miller LJ, Lu M, Lin HY, Kolakowski LF \& Beinborn M 1992 Expression cloning and characterisation of the canine parietal cell gastrin receptor. PNAS 89 3605-3609.

Lee YM, Beinborn M, McBride EW, Lu M, Kolakowski LF \& Kopin AS 1993 The human brain cholecystokinin-B/gastrin receptor. Cloning and characterization. Journal of Biological Chemistry 268 8164-8169.

Mantamadiotis T \& Baldwin GS 1994 The seventh transmembrane domain of gastrin/CCK receptors contributes to non-peptide antagonist binding. Biochemical and Biophysical Research Communications 201 1382-1389.

Moore C, Jie R, Shulkes A \& Baldwin GS 1997 Molecular cloning and sequence of the ovine gastrin gene. DNA Sequence 8 39-44.

Morley JS, Tracy HJ \& Gregory RA 1965 Structure-function relationships in the active $\mathrm{C}$-terminal tetrapeptide sequence of gastrin. Nature 207 1356-1359.

Noble F, Wank S, Crawley J, Bradwejn J, Seroogy K, Hamon M \& Roques B 1999 International Union of Pharmacology. XXI. Structure, distribution, and functions of cholecystokinin receptors. Pharmacological Reviews $\mathbf{5 1}$ 745-781.

Oiry C, Pannequin J, Bernad N, Artis AM, Galleyrand JC, Devin C, Cristau M, Fehrentz JA \& Martinez J 2000 A synthetic glycine-extended bombesin analogue interacts with the GRP/bombesin receptor. European Journal of Pharmacology 403 $17-25$.

Pannequin J, Barnham KJ, Hollande F, Shulkes A, Norton RS \& Baldwin GS 2002 Ferric ions are essential for the biological activity of the hormone glycine-extended gastrin. Journal of Biological Chemistry $27748602-48609$.

Pannequin J, Kovac S, Tantiongco J-P, Norton RS, Shulkes A, Barnham KJ \& Baldwin GS 2004 A novel effect of bismuth ions. Selective inhibition of the biological activity of glycine-extended gastrin. Journal of Biological Chemistry 279 2453-2460.

Peggion E, Mammi S, Palumbo M, Moroder L \& Wunsch E 1983 Interaction of calcium ions with peptide hormones of the gastrin family. Biopolymers 22 2443-2457.

Prigge ST, Mains RE, Eipper BA \& Amzel LM 2000 New insights into copper monooxygenases and peptide amidation: structure, mechanism and function. Cell and Molecular Life Sciences $\mathbf{5 7}$ 1236-1259.

Qian JM, Rowley WH \& Jensen RT 1995 Gastrin and CCK activate phospholipase $\mathrm{C}$ and stimulate pepsinogen release by interacting with two distinct receptors. American Journal of Physiology 264 G718-G727. 
Seva C, Dickinson C \& Yamada T 1994 Growth-promoting effects of glycine-extended progastrin. Science 265 410-412.

Singh P, Velasco M, Given R, Varro A \& Wang TC 2000 Progastrin expression predisposes mice to colon carcinomas and adenomas in response to a chemical carcinogen. Gastroenterology 119 162-171.

Solomon TE, Varga G, Zeng N, Wu SV, Walsh JH \& Reeve JR Jr 2001 Different actions of secretin and Gly-extended secretin predict secretin receptor subtypes. American Journal of Physiology $\mathbf{2 8 0}$ G88-G94.

Torda AE, Baldwin GS \& Norton RS 1985 High resolution proton nuclear magnetic resonance studies of human gastrin. Biochemistry 24 1720-1727.

Tracy HJ \& Gregory RA 1964 Physiological properties of a series of synthetic peptides structurally related to gastrin I. Nature 204 935-938.

Ulrich CD, Ferber I, Holicky E, Hadac E, Buell G \& Miller LJ 1993 Molecular cloning and functional expression of the human gallbladder cholecystokinin A receptor. Biochemical and Biophysical Research Communications 193 204-211.
Wettergren A, Pridal L, Wojdemann M \& Holst JJ 1998 Amidated and non-amidated glucagon-like peptide-1 (GLP-1): non-pancreatic effects (cephalic phase acid secretion) and stability in plasma in humans. Regulatory Peptides 77 83-87.

Winzor DJ \& Sawyer WH 1995 In Quantitative Characterization of Ligand Binding. New York: Wiley-Liss.

Wroblewski LE, Pritchard DM, Carter S \& Varro A 2002 Gastrin-stimulated gastric epithelial cell invasion: the role and mechanism of increased matrix metalloproteinase 9 expression. Biochemical Journal 365 873-879.

Received in final form 8 January 2004

Accepted 31 January 2004

Made available online as an

Accepted Preprint 6 February 2004 